\title{
Italian Catacombs and Their Digital Presence for Underground Heritage Sustainability
}

\author{
Olga Lo Presti *(D) and Maria Rosaria Carli \\ National Research Council-Institute for Studies on the Mediterranean (ISMed), 80134 Naples, Italy; \\ mariarosaria.carli@ismed.cnr.it \\ * Correspondence: olga.lopresti@ismed.cnr.it
}

Citation: Presti, O.L.; Carli, M.R Italian Catacombs and Their Digital Presence for Underground Heritage Sustainability. Sustainability 2021, 13, 12010. https://doi.org/10.3390/ su132112010

Academic Editors: Ernesto Marcheggiani and Giuseppe Pace

Received: 28 September 2021

Accepted: 28 October 2021

Published: 30 October 2021

Publisher's Note: MDPI stays neutral with regard to jurisdictional claims in published maps and institutional affiliations.

Copyright: (c) 2021 by the authors. Licensee MDPI, Basel, Switzerland. This article is an open access article distributed under the terms and conditions of the Creative Commons Attribution (CC BY) license (https:/ / creativecommons.org/licenses/by/ $4.0 /)$.

\begin{abstract}
The Italian catacombs represent one of the most interesting examples of the country's underground built heritage. A strategic use of digital technologies can foster their sustainability by providing virtual access to local communities and tourists, as well as by transferring their value to future generations. Referring to a classification of the catacombs of Italy carried out by the Pontifical Commission for Sacred Archaeology of Vatican City, this paper analyzes the digital presence of this heritage within the contexts of social media, video sharing and navigation platforms in institutional and touristic areas. The emerging results show a good digital presence of this cultural heritage on these platforms. At the same time, they reflect an almost total absence of 3D technologies, virtual reconstructions or augmented reality. Only 2 out of 63 catacombs analyzed offer a photographic overview of the sites through the online Google Art and Culture platform, but this is only a small example of what a virtual visit would offer. The following work is based on this notion, as it aims to demonstrate that this type of underground built heritage still has great potential for the valorization and sustainability of these sites through the use of digital technologies. The use of virtual and augmented reality, enhanced by immersive storytelling, would limit the physical wear and tear on the site, making its conservation sustainable in the long term.
\end{abstract}

Keywords: Italian catacombs; digital presence; long-term sustainability; heritage conservation; digital technology

\section{Introduction}

There are numerous studies [1-3] that agree on the introduction of the concept of sustainability in the conservation of cultural heritage, with the aim of preserving as much culture as possible for future generations. Research [4-7] has shown that cultural heritage is an element of integration for local communities, and it is a strategic element for the sustainable development of an area. The importance of a site's sustainability, in fact, affects the cultural development of communities, as well as the identity and relationships that are formed in the territory in which it is located. Scholars also agree with policy makers on positioning culture as an independent pillar of sustainable development, alongside environmental, social and economic development [8-10]. Knowledge of cultural sites can be fostered with innovative approaches, such as virtual reality and mixed reality, to contribute significantly to preventive conservation and associated risks. These are intangible means aimed at avoiding and minimizing future deterioration or loss by allowing access to a tangible good. They promote a systems approach for heritage.

It is only in the last 20 years or so that attention has begun to focus on the relationship between cultural heritage and sustainability; examples of this are as follows [11]: the 2002 UNESCO Budapest Declaration, which expresses the need to balance the aspects of conservation with those of sustainability and development through activities aimed at social and economic development and the quality of life of communities; and The Florence Declaration on Heritage and Landscape as Human Value by ICOMOS 2014, which 
introduced the concept of landscape- and community-based planning to integrate the economic, social and environmental processes of territories.

The studies that have dealt with the role of sustainable development in the cultural sphere have analyzed this phenomenon via different approaches, including the following: in relation to cultural tourism [12,13]; considering the relationships between cultural sustainability, identity and community [14]; collaborations between world heritage sites [15]; aspects of political planning and collaborations between stakeholders [16]; urban regeneration projects $[17,18]$; and the preservation and development of historic centers for tourism purposes without dealing with cultural regeneration aspects [19].

Cultural heritage has a strategic role in poverty reduction through economic growth, tourism and job creation [20]. Furthermore, it brings local communities together in learning about their heritage, preserving it and transferring it to subsequent generations [12].

Despite there being numerous studies, some of which have been cited, there are still very few studies on cultural sustainability below ground. Moreover, research on the use of multimedia and interactive technologies as a strategic variable for a sustainable use of cultural heritage is still in its infancy. Studies in this regard have focused heavily on tourism and enhancement aspects [21-24]; however, what now needs to be performed are studies that draw attention to state-of-the-art technologies with respect to the use of 3D technologies, virtual reconstructions or augmented reality for the preservation of material heritage and for the dissemination of intangible heritage, outlining the prospects for future development.

The work presented here focuses on the analysis of the digital presence in the catacombs of Italy, an example of underground cultural heritage among the most exposed to the risk of deterioration over time and in urgent need of interventions for its sustainability.

In our approach, virtual, immersive and augmented reality technologies are mainly thought of as visit support for closed and deteriorating sites, which, in our sample, represent $30 \%$ of cases.

\section{Catacombs of Italy}

The catacombs are underground cemeteries that were used in the past by the Etruscans and Jews, but whose use became more widespread in Rome in the first centuries of Christianity, between the end of the second and the beginning of the third century AD, during the pontificate of Pope Zephyrinus. The catacombs were used to bury the dead in underground spaces in order to wait, according to the principles of Christianity, for their resurrection. There is also a large number of catacombs in the central and the southern islands in Italy, where the existence of tuff made them possible due to the ease of excavation.

Generally, access to the catacombs requires the use of stairs to reach tunnels in the walls where the loculi are arranged. This is the most common arrangement for people, but there are catacombs in which high-ranking people were buried underground in real burial chambers [25].

The Pontifical Commission for Sacred Archaeology of Vatican City, which is entrusted with all the existing catacombs on Italian territory, is in charge of any work to be carried out and establishes the rules for public access. It has worked to classify and make accessible information on this underground heritage with the project Catacombs of Italy. This project is presented at catacombeditalia.va, where the catacombs are fully described and organized by region and type of opening.

The platform provides an interesting census of the catacombs of Italy from which authors can start assessing the possibility of developing a digital presence as an intervention to promote long-term sustainability. This study classifies this heritage according to the current use of different technological platforms for the digital communication of underground heritage addressed to local communities and visitors. Only one of the catacombs is subject to multimedia tours in collaboration with the Google Maps portal. This classification represents the starting point for assessing the use of multimedia and interactive 
technologies as a strategic variable for the sustainability of the catacombs, i.e., cultural heritage underground.

\section{Materials and Methods}

The database, "Catacombs of Italy" project of the Pontifical Commission for Sacred Archaeology of Vatican City, was used to study digital presence in Italian catacombs. The project has surveyed 63 Christian catacombs in Italy. In the Lazio region, there are 46 catacombs, 31 of which are around the city of Rome. The greatest presence, therefore, is in central Italy. The other 17, with the exception of only 1 in Tuscany, are distributed throughout southern Italy and the islands of Sicily and Sardinia.

The first phase of the analysis selected the sites by type of visit: open to the public, open on request, special visits and closed to the public.

The second phase of the analysis investigated the presence of the website, social pages on Facebook, Instagram and Twitter, and the digital presence on YouTube and Google Arts and Culture platforms.

The third phase of the analysis focused on the number of comments left by visitors on the review platforms TripAdvisor and Google Reviews.

The study of the platforms was conducted between the 21 May 2021 and the 21 July 2021 in both Italian and English languages. The results are presented in the next section.

\section{Results}

The abovementioned census of catacombs and hypogea-which are underground chambers dug into the ground, used as dwellings, burial grounds or places of worshipconcerns 63 sites in eight regions of central Italy, the south and the islands, distributed as follows (Table 1):

Table 1. List of catacombs and hypogea in the Italian regions and in the city of Rome, 2021.

\begin{tabular}{cl}
\hline Region/City & \multicolumn{1}{c}{ Name of Catacombs } \\
\hline \multirow{2}{*}{ Abruzzo } & Catacomba di S. Vittorino ad Amiterno (AQ) \\
& Catacomba di Castelvecchio Subequo (AQ) \\
\hline Apulia & Complesso monumentale di Lamapopoli (Canosa, BT) \\
\hline \multirow{3}{*}{ Campania } & Catacomba di S. Gaudioso (NA) \\
& Catacomba di S. Gennaro (NA) \\
& Catacomba di S. Efebo (NA) \\
& Catacomba di S. Severo (NA) \\
& Catacomba di S. Cristina a Bolsena (VT) \\
& Catacomba di Colle S. Quirico a Paliano (FR) \\
& Catacomba di S. Eutizio, Soriano nel Cimmino (VT) \\
& Catacomba di S. Savinilla a Nepi (VT) \\
& Catacomba del Ss. Gratiliano e Felicissima, Falerii Novi (VT) \\
& Catacomba di Visentium, Capodimonte VT \\
& Catacomba di Gratte, Bolsena (VT) \\
& Catacomba di S. Vittoria a Monteleone Sabino (RI) \\
& Catacomba Ad Decimum, Grottaferrata (RM) \\
& Catacomba di Monte Stallone a Formello (RM) \\
& Catacomba ad Vicesimum, Morlupo (RM) \\
& Catacomba di S. Senatore ad Albano (RM) \\
& Catacomba di “Monte della Casetta”, Capena (RM) \\
& Catacomba di S. Teodora a Rignano Flaminio (RM) \\
Lazio & Catacomba di S. Ilario “ad Bivium” presso Valmontone (RM) \\
&
\end{tabular}


Table 1. Cont.

\begin{tabular}{|c|c|}
\hline Region/City & Name of Catacombs \\
\hline Sardinia & Catacomba di S. Antioco (CI) \\
\hline Sicily & $\begin{array}{l}\text { Catacomba di Porta d'Ossuna (PA) } \\
\text { Catacomba di S. Giovanni a Siracusa (SR) } \\
\text { Catacomba di Santa Lucia (SR) } \\
\text { Catacomba di Vigna Cassia (SR) } \\
\text { Catacomba di Villagrazia di Carini (PA) }\end{array}$ \\
\hline Tuscany & $\begin{array}{l}\text { Catacomba dell'Isola di Pianosa Portoferraio (LI) } \\
\text { Catacomba di S. Caterina Chiusi (SI) } \\
\text { Catacomba di S. Mustiola Chiusi (SI) }\end{array}$ \\
\hline Umbria & Catacomba di Villa S. Faustino a Massa Martana (PG) \\
\hline Rome & $\begin{array}{l}\text { Catacomba di Domitilla (RM) } \\
\text { Catacomba di S. Pancrazio (RM) } \\
\text { Catacomba di S. Agnese (RM) } \\
\text { Catacomba di S. Callisto (RM) } \\
\text { Catacomba di Priscilla (RM) } \\
\text { Catacomba di S. Sebastiano (RM) } \\
\text { Catacomba di Generosa (RM) } \\
\text { Cimitero Maggiore (RM) } \\
\text { Catacomba di S. Ermete o Bassilla (RM) } \\
\text { Catacomba di S. Felicita o di Massimo (RM) } \\
\text { Catacomba di S. Lorenzo (o Ciriaca) (RM) } \\
\text { Catacomba di Vigna Chiaraviglio (RM) } \\
\text { Catacomba di Commodilla (RM) } \\
\text { Catacomba di S. Tecla (RM) } \\
\text { Museo della Torretta e Cripte di Lucina (RM) } \\
\text { Museo e Catacomba di Pretestato (RM) } \\
\text { Ipogeo degli Aureli in Viale Manzoni (RM) } \\
\text { Museo di Domitilla e Regione dei Fornai (RM) } \\
\text { Catacomba Anonima di Via Anapo (RM) } \\
\text { Catacomba dei Giordani (RM) } \\
\text { Catacomba di S. Valentino (RM) } \\
\text { Catacomba di Vibia (RM) } \\
\text { Catacomba di S. Ippolito (RM) } \\
\text { Catacomba di Panfilo (RM) } \\
\text { Catacomba dei SS. Marco, Marcelliano e Damaso (RM) } \\
\text { Catacomba di Calepodio (RM) } \\
\text { Ipogeo di Via Dino Compagni (RM) } \\
\text { Catacomba della Nunziatella (RM) } \\
\text { Catacomba di Roma Vecchia, Parco degli Acquedotti (RM) } \\
\text { Catacomba di S. Zotico, Vermicino (RM) } \\
\text { Catacomba di S. Alessandro sulla Via Nomentana (RM) }\end{array}$ \\
\hline
\end{tabular}

Source: Our elaboration from the project data of the Catacombs of Italy.

As can be seen more graphically in Figure 1, the city of Rome preserves almost half (31) of this cultural heritage, followed by the region of Lazio with 15 catacombs, Sicily with 5, Campania with 4, Tuscany with 3, Abruzzo with 2 and, finally, only 1 for Apulia, Sardinia and Umbria, respectively. 


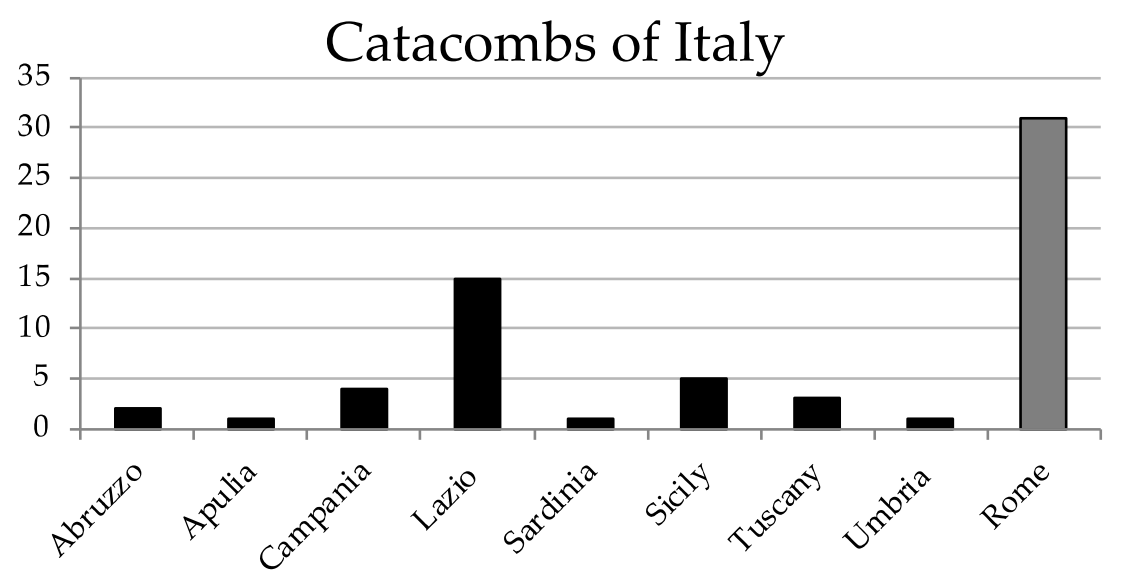

Figure 1. Distribution of catacombs and hypogea by regions and in the city of Rome, 2021. Source: Our elaboration from the project data of the Catacombs of Italy.

\subsection{Type of Visit}

The first stage of the analysis investigated the type of visit: open to the public, open on request, special visits or closed to the public (Figure 2).

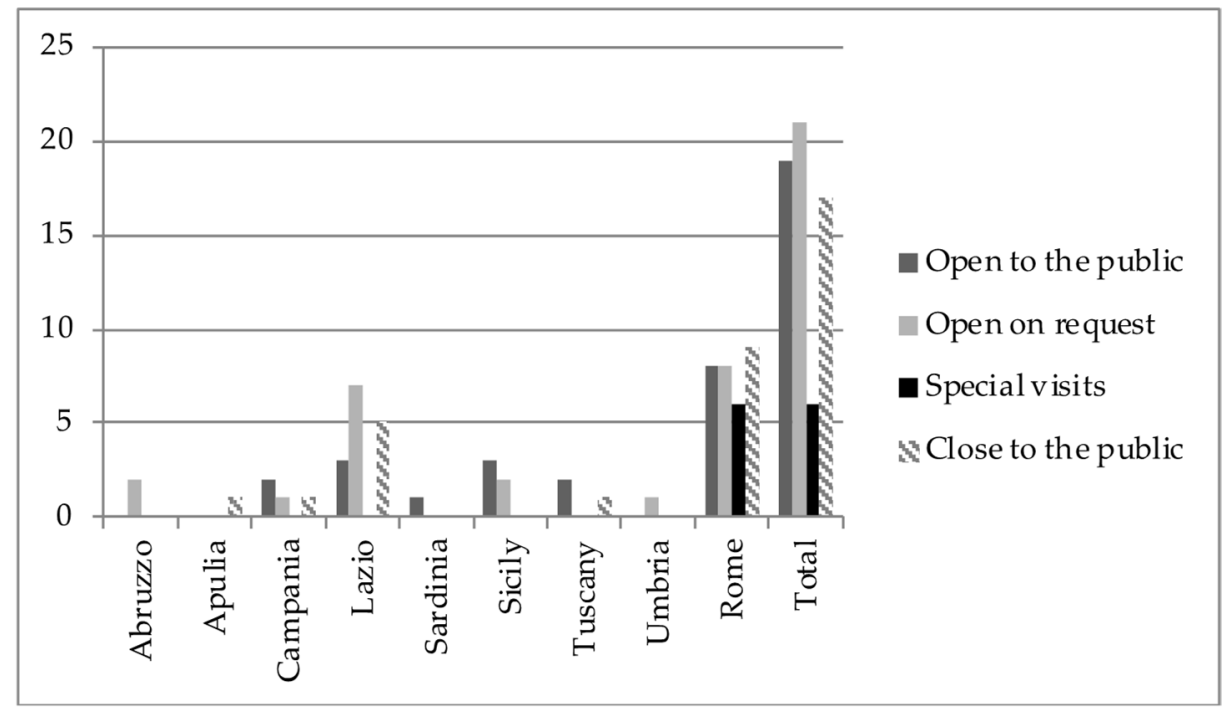

Figure 2. Type of visit of the catacombs. Regional data, 2021. Source: Our elaboration from Catacombs of Italy project data.

The graph shows the catacombs by region, distinguishing between those that are closed and those that are open. For the latter, it identifies the type of visit: by request, special visit or open to all.

In the city of Rome, the number of closed catacombs (9) is greater than those open or open on request (8). In the region of Lazio, only three catacombs are open to the public, five are closed and seven are open on request. These data, however, refer to the survey period, which, as we have said, was conducted from 21 May 2021 to 21 July 2021, i.e., during the emergency period for the COVID-19 pandemic when security measures led to the closure of many cultural sites. In Sicily, Tuscany and Campania, the catacombs were kept open with the exception of the catacomb of S. Severo in Campania and the catacombs on the island of Pianosa in Tuscany. The Cemetery Complex of Lamapopoli, the only catacomb present in Puglia, is also presently closed. In the last two regions, where there is only one 
catacomb, that of S. Antioco in Sardinia, the catacomb remains open to the public, while in Umbria, the Catacomb of Villa S. Faustino opens only on request. Overall, over $65 \%$ of the catacombs are open to the public (41 out of 63).

\subsection{Multimedia Tools and Social Pages}

The second phase of analysis investigated the level of digital presence of the catacombs on the Internet. The existence of a website and social pages on Facebook, Instagram and Twitter were first checked (Table 2).

Table 2. Digital presence by type of visit, 2021.

\begin{tabular}{ccccc}
\hline & Open to the Public & Open on Request & Special Visits & Closed to the Public \\
& $\mathbf{1 8}$ & $\mathbf{2 0}$ & $\mathbf{6}$ & $\mathbf{1 9}$ \\
\hline SOCIAL MEDIA & 17 & 19 & 6 & 19 \\
Website & 14 & 13 & 1 & 6 \\
Facebook & 8 & 1 & 0 & 3 \\
Instagram & 5 & 2 & 1 & 3 \\
Twitter & 5 & & \\
\hline
\end{tabular}

Source: Our elaboration from the project data of the Catacombs of Italy.

Abruzzo and Tuscany are the regions that rely the least on social media, limiting their 147 online presences to their website (Figure 3). Their catacombs are only advertised on the Internet with the proposal of a virtual tour on YouTube. In the other regions, the use of social media is more widespread. Campania makes full use of all available social channels, while Apulia, Tuscany and Abruzzo totally ignore the opportunities offered by Instagram and Twitter, and Umbria only uses Facebook. The total absence on Instagram and Twitter channels of the catacombs in the Lazio region (with the exception of Rome) represents a significant shortcoming in terms of both the quantity and management and the marketing strategy.

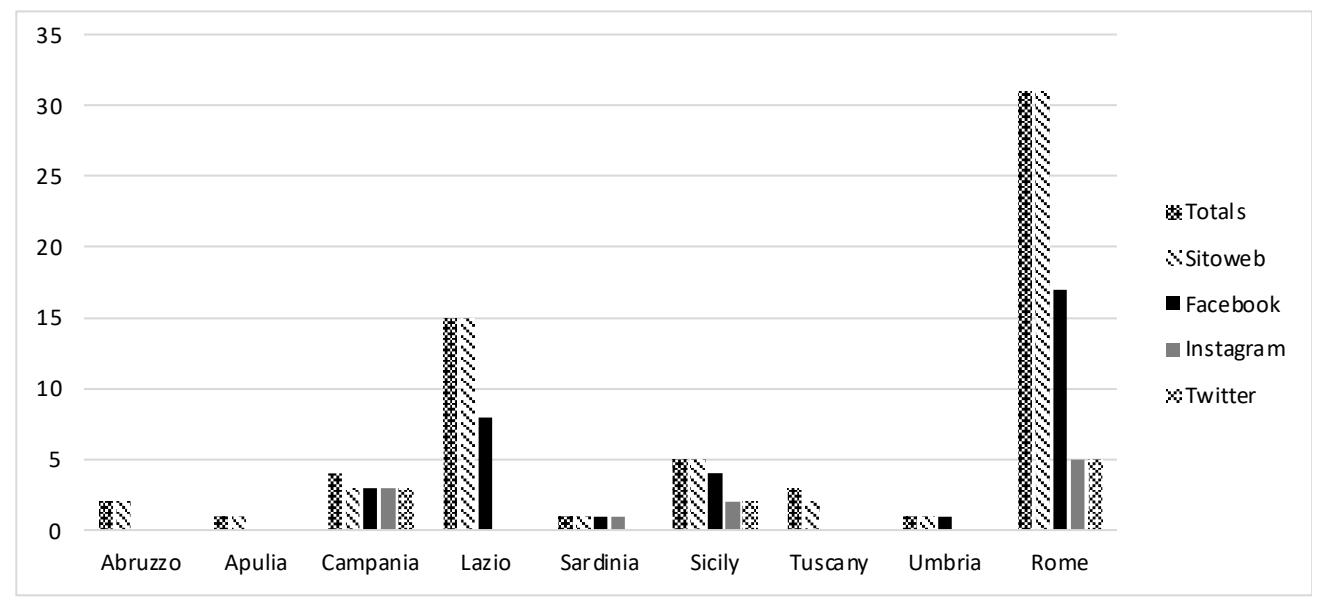

Figure 3. Use of social media for digital communication of the catacombs. Regional data 2021. Source: Our elaboration from Catacombs of Italy project data.

Abruzzo and Tuscany are the regions that rely the least on social media, limiting their online presence to their websites (Figure 3). Their catacombs are advertised exclusively on their websites with the proposal of a virtual tour on YouTube. In the other regions, the use of social media is more widespread. Almost all the places surveyed have a website (with the exception of two). Campania makes full use of all the available social channels, while the situations in the other regions are different. In particular, Apulia, Tuscany, Abruzzo and Umbria totally ignore the opportunities offered by Instagram and Twitter, but the number of catacombs present on their territory is minimal (Table 1). The absence of these channels for all the catacombs present in the Lazio region (with the exception of Rome), on the other 
hand, represents a significant gap in terms of both the quantity and management and the marketing strategy.

In particular, this work aimed to assess the presence of the underground sites of the catacombs in a virtual and immersive digital environment. The survey was conducted by analyzing the YouTube and Google Arts and Culture platforms (Table 3). The latter, in particular, appears to be experiencing considerable growth worldwide. In the last 10 years - especially during the lockdown period due to the COVID19 pandemic — there has been an increase in its use for museums, art galleries and various cultural institutions to enable them to take advantage of cultural offers and create alternative visitation models at a distance for the public.

Table 3. Presence by type of digital visit, 2021.

\begin{tabular}{ccccc}
\hline & Open to the Public & Open on Request & Special Visits & Close to the Public \\
& $\mathbf{1 8}$ & $\mathbf{2 0}$ & $\mathbf{6}$ & $\mathbf{1 9}$ \\
\hline MULTIMEDIA TOUR & & & 0 & 1 \\
Google Maps & 0 & 0 & 0 & 0 \\
Google Art and Culture & 2 & 0 & 5 & 0 \\
$\quad$ YouTube & 14 & 12 & 0 & 0 \\
VIRTUAL TOUR & 0 & 0 & & 0 \\
IMMERSIVE REALITY & & & \\
\hline
\end{tabular}

Source: Our elaboration from the project data of the Catacombs of Italy.

The survey showed that almost all catacombs in the city of Rome (26 out of a total of 31) offered multimedia tours on YouTube. In Naples, multimedia tours of the Catacombs of San Gaudioso and San Gennaro are available on the Google Arts and Culture platform. Four out of five catacombs in Sicily, one out of two in Abruzzo and one out of three in Tuscany are also present on YouTube, while the catacombs in Umbria and Apulia are completely absent. The hypogeum of Via Dino Compagni in Rome is present, again in multimedia forms, on Google Maps.

None of them, however, use augmented or immersive reality tools (Table 2). Globally, distinguishing the catacombs by type of visit, it can be seen that the sites closed to the public are also those that offer fewer opportunities for multimedia visits, although interest in them-in view of the reviews about them-is still perfectly average compared to the catacombs open on request or for special visits.

With regard to the type of visit, it was ascertained that almost all the places surveyed had a website (with the exception of two) and that all the closed catacombs also had websites. Additionally, $78 \%$ of the open catacombs and $65 \%$ of those open on request are present on Facebook, while just over 31\% of the closed catacombs use this social channel. There is much less presence on the social channels of Instagram and Twitter. For instance, $44.4 \%$ of open catacombs disseminate content on these channels, while only $15.8 \%$ of the catacombs closed to the public do so. If we look at the social presence by region, Abruzzo and Tuscany rely less on social media, limiting their online presence only to their websites (Figure 3).

\subsection{Reviews}

The last phase of the analysis focused on the comments left by visitors on the review platforms TripAdvisor and Google Reviews. In total, $73 \%$ of the catacombs (46 out of 63 ) received reviews on at least one of the channels analyzed; 17 did not receive any reviews. With regard to the type of opening, in our analysis conducted for each catacomb, it emerged that all the catacombs open to the public received reviews on both platforms (Table 4); for the catacombs with another type of visit, comments emerged showing regret about finding the places closed or not accessible once reached, and there were even comments about it being impossible to find complete information about a place before, or as an alternative to, visiting. 
Table 4. Reviews in relation to type of visit, 2021.

\begin{tabular}{ccccc}
\hline & Open to the Public & Open on Request & Closed to the Public & Special Visits \\
& $\mathbf{1 8}$ & $\mathbf{2 0}$ & $\mathbf{6}$ & $\mathbf{6}$ \\
\hline REVIEWS & & & 11 & 4 \\
TripAdvisor & 18 & 11 & 8 & 3 \\
Google Reviews & 17 & 11 & 8 \\
\hline
\end{tabular}

Source: Our elaboration from Catacombs of Italy project data.

The figure for the 17 catacombs that did not receive any reviews is very interesting. Of these, eight are open on request, two are open only for special visits and eight are closed to the public. In particular, there are eight catacombs closed to the public for which there is no multimedia tour, and no reviews were found for seven of them. This confirms that interest is only aroused when it is possible to see a site, and even more so when there is a real visitor experience or access to the site. A realistic experience, however, can also be had with the help of technology, using virtual or augmented reality.

\section{Discussion}

The contents of the reviews leave no doubt as to the weaknesses of the system of conservation, as well as the use and valorization of the underground sites of the catacombs. The states of disappointment and the consequent mechanism of detachment in the visitor are obvious and could certainly be remedied by the use of virtual technologies that would allow for better management of information and a radical change in the management of assets that could be made 'visitable' without the use of staff.

It should be pointed out that the videos available on YouTube that offer the possibility of observing the catacombs more closely are not virtual tours: YouTube, in fact, uses a non-interactive mode of communication that passively places the user in relation to the transmitted narrative. Technological progress, on the other hand, is creating new research opportunities for virtual heritage and new tools for the fruition of objects, monuments and environments, using agent-based models, evolutionary and, above all, reactive virtual environments. For example, virtual reality reconstructs a 3D environment that is intended to be immersive, is often interactive and can simulate the physical presence of a user in the environment. Implementation is usually executed through a special headset through which the augmented reality adds sensory input to the brain in addition to that of the surrounding environment.

As Peterson [26] makes clear in relation to virtual reality, the brain receives sensory input from a time and place different from those in which the person is, with the possibility of interacting as if the body were actually there. Virtual reality, mixed reality and augmented reality projects represent new and exciting ways to learn and appreciate cultural sites and provide enticing new ways of engaging audiences with the past [27].

These new ways of discovering, viewing and manipulating intangible information represent a new phase of research: virtual heritage. This is the use of digital technology and virtual environments to research, preserve and transmit our cultural heritage. According to Cameron and Kenderdine [28] (p. 10), the term 'virtual cultural heritage' is generally accepted to mean virtual reality ( $3 \mathrm{D}$ and $4 \mathrm{D}$ computational and computer graphics systems that support real-time, immersive, and interactive operations), employed specifically for the presentation, preservation, conservation and documentation of natural and cultural heritage.

The sites of the catacombs, in particular, appear to be an ideal laboratory for the experimentation of virtual heritage. They are culturally and historically significant places that should be preserved as much as possible. They are often located in areas that are very difficult or dangerous to reach, and their fragility is compromised by several factors such as humidity, temperature, air quality, light, etc., that can be altered by visitors, unconsciously or not. Interventions on their structure is inadvisable and also technically demanding and expensive. For these reasons, physical accessibility is a real problem, especially when it 
comes to allowing the public to visit the catacombs. Traditional ways of accessing cultural sites are in fact often unsustainable, especially from an environmental point of view, and certainly harmful in the longer term. It is important to underline that this is a problem for all types of access, not only for people with limited mobility [29].

The use of these technologies would allow, as we have suggested, for the visit of closed or deteriorating catacombs with clear aims of sustainability. On the other hand, access to a virtual representation could also stimulate an increase in visits, thus thwarting efforts to preserve the property, which could be solved with a quota system. At the same time, the latter aspect may call for a funding intervention by the Pontifical Commission for Sacred Archaeology of Vatican City to promote its preservation and enhancement.

A possible solution to overcome these problems of accessibility and preservation is to use virtual reality technology such as mixed reality within these heritage sites. This is a variant of virtual reality in which part of the computer-rendered 3D elements and part of the photographed real elements are combined into an immersive experience that simulates the physical presence of the user in the environment. These tools would make it much easier to set up educational courses for schools in the area aimed at training them to trigger a process of awareness of the past, their identity and local history. This awareness is a valuable tool to become promoters of their territory and to transfer, from generation to generation, knowledge, awareness and, above all, preserved goods. This approach would build resilience by encouraging community-based approaches for disaster risk reduction of heritage by promoting a systems approach for heritage, thus strengthening its links to the social and environmental dimensions of sustainable development. These are very important steps in the sustainability process that the Catholic Church could make its own.

According to European Commission: "Cultural heritage enriches the individual lives of citizens, is a driving force for the cultural and creative sectors and plays a role in creating and strengthening Europe's social capital. It is also an important resource for economic growth, employment and social cohesion, offering the potential to revitalize rural areas and promote sustainable tourism" [30].

Last but not least, the development of technologies for the promotion of cultural heritage can be of public and philanthropic interest. One of the possible financial commitments, not to mention the fact that it is not very expensive, could be virtual or immersive projects that make these places accessible at a distance through an engaging interaction configured to the needs of individual visitors.

Author Contributions: Both authors (O.L.P. and M.R.C.) contributed to writing the manuscript. All authors have read and agreed to the published version of the manuscript.

Funding: This research was funded by CNR-Institute for Studies on the Mediterranean (ISMed).

Institutional Review Board Statement: Not applicable.

Informed Consent Statement: Not applicable.

Data Availability Statement: Not applicable.

Conflicts of Interest: The authors declare no conflict of interest.

\section{References}

1. Pesme, C. Contemporary Theory of Conservation. Stud. Conserv. 2010, 55, 315-316. [CrossRef]

2. Clark, K. Capturing the Public Value of Heritage. In Proceedings of the London Conference, Swindon, UK, 25-26 January 2006.

3. United Nations Educational Scientific and Cultural Organization. Rio20 United Nations Conference on Sustainable Development 1-53. In Proceedings of the Future We Want: Final Document of the Rio+20 Conference, Rio de Janeiro, Brazil, $20-22$ June 2012.

4. United Cities and Local Governments (UCLG). Culture: Fourth Pillar of Sustainable Development. 2010. Available online: www.uclg.org (accessed on 10 June 2021).

5. Jin, Y. GIS-based and Statistical Approaches to Explore Relationship between Heritage and Urban Sustainable Development: A Cases Study on Liverpool, England; University College London: London, UK, 2018. 
6. Murti, R. Natural Heritage-A Nature based Solution for Resilience to Disasters. In Proceedings of the 3rd International Symposium on Nature-Culture Linkages in Heritage Conservation in Asia and the Pacific: Disaster and Resilience, Tsukuba, Japan, 21 September-1 October 2018.

7. Pereira Roders, A.; van Oers, R. Bridging cultural heritage and sustainable development. J. Cult. Herit. Manag. Sustain. Dev. 2011, 1, 5-14. [CrossRef]

8. Kou, H.; Zhou, J.; Chen, J.; Zhang, S. Conservation for Sustainable Development: The Sustainability Evaluation of the Xijie Historic District, Dujiangyan City, China. Sustainability 2018, 10, 4645. [CrossRef]

9. Keitumetse, S.O. Cultural resources as sustainability enablers: Towards a community-based cultural heritage resources management (COBACHREM) model. J. Sustain. Tour. 2014, 6, 70-85. [CrossRef]

10. Rosetti, I.; Pereira Roders, A.; Jacobs, M. Heritage and sustainability: A reflection on the role of partecipatory heritage practices in sustainable development. In Proceedings of the LDE Heritage Conference on Heritage and the Sustainable Development Goals Proceedings, Delft, Holand, 26-28 November 2019.

11. Pace, G.; Ismed-Cnr, I. Underground Built Heritage as catalyser for Community Valorisation. In Underground Built Heritage Valorisation. A handbook, Proceedings of the First Training School; Salvarani, R., Pace, G., Eds.; CNR Edizioni: Rome, Italy, 2019. [CrossRef]

12. Sharpley, R. Tourism and Sustainable Development: Exploring the Theoretical Divide. J. Sustain. Tour. 2000, 8, 1-19. [CrossRef]

13. Cole, D. Exploring the Sustainability of Mining Heritage Tourism. J. Sustain. Tour. 2004, 12, 480-494. [CrossRef]

14. Rodwell, D. Sustainability and the Holistic Approach to the Conservation of Historic Cities. J. Arch. Conserv. 2003, 9, 58-73. [CrossRef]

15. Wilson, L.-A.; Boyle, E. Interorganisational collaboration at UK World Heritage Sites. Leadersh. Organ. Dev. J. 2006, 27, 501-523. [CrossRef]

16. Landorf, C. Managing for sustainable tourism: A review of six cultural World Heritage Sites. J. Sustain. Tour. 2009, 17, 53-70. [CrossRef]

17. Ryberg, S.R. Neighborhood Stabilization through Historic Preservation: An Analysis of Historic Preservation and Community Development in Cleveland, Providence, Houston and Seattle; University of Pennsylvania: Philadelphia, PA, USA, 2010.

18. Snyder, M.R. The Role of Heritage Conservation Districts in Achieving Community Improvement; University of Waterloo: Waterloo, ON, Canada, 2008.

19. Boeri, A.; Gaspari, J.; Gianfrate, V.; Longo, D.; Pussetti, C. The adaptive reuse of historic city centres. Bologna and Lisbon: Solutions for urban regeneration. J. Technol. Archit. Environ. 2016, 230-237.

20. ICOMOS. Cultural Heritage, the UN Sustainable Development Goals, and the New Urban Agenda. 2016, p. 23. Available online: http:/ / www.usicomos.org/wp-content/uploads/2016/05/Final-Concept-Note.pdf (accessed on 15 July 2021).

21. Cameron, F.; Kenderdine, S. Beyond the Cult of the Replicant: Museums and Historical Digital Objects: Traditional Concerns, New Discourses. 2007. Available online: https://researchdirect.westernsydneyedu.au/islandora/object/uws:11475/ (accessed on 12 October 2021).

22. Krubu, D.E.; Osawaru, K.E. The Impact of Information and Communication Technology (ICT) in Nigerian University Librarides, 2011, Library Philosophy and Practice. Available online: https:/ /digitalcommons.unl.edu/cgi/viewcontent.cgi?article=1614 \&context (accessed on 18 October 2021).

23. Pujol, L.; Champion, E. Evaluating presence in cultural heritage projects. Int. J. Heritage Stud. 2012, 18, 83-102. [CrossRef]

24. Loach, K.; Rowley, J.; Griffiths, J. Cultural sustainability as a strategy for the survival of museums and libraries. Int. J. Cul. Pol. 2019, 23, 58-70. [CrossRef]

25. Catacombe d'Italia. Available online: http:/ / www.catacombeditalia.va/content/archeologiasacra/it.html (accessed on 30 June 2021).

26. Peterson, J. Virtual Reality, Augmented Reality, and Mixed Reality Definitions (Version 1.0 07/07/2017) CEO ContentBridge Systems $\mathcal{E}$ Ramón Bretón, CTO 3rd i QC; USC Entertainment Technology Center, 2017 with Input from Philip Lelyveld. Available online: https://godigitalmg.com/wp-content/themes/godigital/media/whitepaper/2017-EMA-VR-AR-MR-Definitions-Final1.pdf (accessed on 6 October 2021).

27. Seychell, D.; Dingli, A. Rediscovering Heritage through Technology. Stud. Comput. Intel. 2020, 859.

28. Cameron, F.; Kenderdine, S. Theorizing Digital Cultural Heritage: A Critical Discourse; Media in Transition; The MIT Press: Cambridge, UK, 2007.

29. Peruzzi, L.; Google Arts \& Culture. Una banca dati gratuita tra informazione ed emozione. Bibl. Og. 2019, 37, 4-20.

30. European Commission. Available online: https:/ / ec.europa.eu/culture/policies/selected-themes/cultural-heritage (accessed on 30 August 2021). 